\title{
French government outlines new university reforms
}

\section{Paris}

Just over a year after a disastrous attempt at university reforms was aborted, the French government has decided to have a second try. An outline of the new proposals was published last week ( 7 January) by minister-delegate for research and higher education Jacques Valade, following the final report (Demain l'Université) of a 69-member commission (see Nature 328, 102; 1987). Inevitably controversial - the historic Paris riots of 1968 were intimately linked to problems in the French system of education - the present proposals have so far provoked only scepticism.

Although Valade's remit also embraces research, his outline reforms apply only to university higher education. Unlike those elsewhere, French universities have a monopoly on neither higher education nor research. Basic research is almost entirely carried out in state research establishments with a separate funding structure and administration, themselves targeted for reform, while the elite grandes écoles (engineering and military academies) and private colleges cream off many of the brightest undergraduates in science and engineering.

The highest of Valade's four major priorities is an attack on the present 'paradoxical' university admissions procedure. In order to compete with other institutions of higher education, access to degree courses is selective even though universities have a statutory obligation to accept any candidate with a baccalauréat (examinations sat at the end of secondary education). Students not admitted to a degree course, or who choose less specialized studies, are automatically able to register for a two-year course leading to a national diploma of general higher education (DEUG).

But the DEUG has a high failure rate, attributed to high staff-student ratios and uneven student abilities. Attempts to introduce other short courses geared to vocational training or degree entrance have also been forced, by oversubscription, to specify higher admission requirements.

Valade feels that this 'selection by failure' is unacceptable and has adopted his advisory committee's proposal for a new kind of 'university college' that offers short courses leading to national diplomas or preparation for degree-level studies. These colleges, which would be governed and financed by the universities, although geographically separate, should, Valade feels, be "better adapted" to students" abilities and to the "rapidly changing employment opportunities" available.
Although the opposition socialist party also recognizes the need to tackle the "first cycle' (first two years) of university education, the idea of university colleges has already raised the hackles of left-wing lecturers' unions. They feel that the scheme is no more than a watered-down version of the two-tier structure proposed by Valade's predecessor, Alain Devaquet, which led to student riots and his resignation in December 1986 (see Nature 324, 501; 1986).

Valade's proposals, which also provide for greater autonomy of university gov-

erning bodies, come just a few weeks after his colleague, education minister René Morony, announced plans for a FF28,000 million ( $£ 2,800$ million) overhaul of primary and secondary education. While the cost of Morony's plan has raised eyebrows in the Ministry of Finance, the absence of figures for Valade's scheme has led to incredulity - particularly with respect to plans to increase student grants and to raise student intake by the year 2000 .

The French press and government critics are saying that the proposed reforms are no more than an attempt to enter May's presidential elections with an education policy based on what Valade has called a "consensus" — the "independent and impartial" report of his advisory committee.

Peter Coles

\section{Universities defy South African government}

Cape Town

IN South Africa, the academic year has drawn to a close without the government enforcing the regulations promulgated on 16 October (see Nature 330, 4; 1987) empowering it to cut subsidies in the face of political activity on university campuses.

The most radical act of defiance of the regulations so far has come from the University of the Western Cape (UWC). Its students responded with a week-long boycott of lectures, an incident which should, in terms of the regulations, have been reported to the government with a notification of what action was being taken against offenders. Instead, the university administration simply notified the Minister of Education and Culture for Coloured Affairs, Mr Carter Ebrahim, that it did not intend reporting on the boycott or taking any action.

The administration of the regulations is complicated by the bizarre fact that there are no fewer than five ministers responsible for education in South Africa. The regulations are the brainchild of Minister of National Education F.W. de Klerk, who assumes a coordinating role and is also front-runner in the stakes to succeed P.W. Botha as state president. Responsibility for the implementation of the regulations, however, lies with the minister in whose department the particular university in question falls. In the case of the 'white' universities, four of which are open to all races, this is white education minister Piet Clase, whereas the ethnic universities (one for each African tribal group) are the responsibility of the minister for African education, Dr Gerrit Viljoen, himself a former principal of the Rand Afrikaans University. UWC (also now open) falls under the aegis of coloured affairs minister Ebrahim and the University of Durban-Westville falls under Indian education minister K. Ramduth.
These ministers do not appear to have entirely congruent views on the regulations. Ebrahim has already omitted to act in the case of UWC. When the rector of the University of Zululand, Professor A.C. Nkabinde, objected to Viljoen about "the whole concept of a university being policed by an education authority", the minister reportedly agreed with him and assured him that his university would not have the regulations applied.

Three universities are applying to the Supreme Court to have the regulations declared invalid on the grounds that they are both ultra vires and so vague and loosely worded as to make their implementation impossible. Papers have already been filed in the Supreme Court in Pietermaritzburg by the University of Natal, and the case is expected to be heard on 9 February. In the same week, the Cape Town Supreme Court will hear separate applications by the Universities of Cape Town and the Western Cape. Rhodes University and the University of the Witwatersrand have decided not to proceed with court proceedings, apparently on the grounds that their counsel is not of the opinion that legal action is likely to be successful.

It is rumoured that the chancellors of the universities that have opposed the regulations will be petitioning the government soon, in an attempt to prevent the regulations being implemented once the academic year starts again in midFebruary. Such a deputation is likely to include two of the most powerful men in South African industry: Harry Oppenheimer, retired chairman of AngloAmerican Corporation (South Africa's largest mining house) and chancellor of the University of Cape Town, and Mike Rosholt, chancellor of the University of the Witwatersrand and chief executive of Barlow Rand, the country's largest manufacturing company. 